\title{
FORECASTING ANALYSIS OF ORGANIC RED RICE'S DEMAND USING ARTIFICIAL NEURAL NETWORKS
}

\author{
Abdul Holik ${ }^{* 11}$, Riza Rahimi Bachtiar*), and Shinta Setiadevi*) \\ *) Agribusiness Department, Politeknik Negeri Banyuwangi \\ Jl. Raya Jember Km 13 Labanasem, Kabat, Banyuwangi
}

\begin{abstract}
Consumer demand for organic red rice in Banyuwangi is always fluctuating each period. This study aims to design an Artificial Neural Network (ANN) Architecture and forecast the demand of Red Rice Production at PT. Sirtanio Organik Indonesia located at Singojuruh, Banyuwangi. Demand forecasting is the level of demand product that is expected to be realized for a certain period in the future. The data used as input for this study are product prices, stocks, sales and demand in 2015-2017. This research used six architectures and Algorithm that used is Artificial Neural Network Backpropagation. The research result showed that highest demand for organic red rice is in August of 2018 and the lowest in April of 2018. The conclusion of this research showed that the best architecture is 3-20-1 with MSE value of 0.002 and R squared of 0.859 and this model is well used to predict organic red rice demand in Banyuwangi.
\end{abstract}

Keywords: Artificial Neural Network, backpropagation, Banyuwangi, MSE, organic red rice

\begin{abstract}
Abstrak: Permintaan konsumen terhadap beras merah organik di Banyuwangi selalu berfluktuasi setiap periode. Penelitian ini bertujuan untuk merancang Arsitektur Jaringan Syaraf Tiruan (JST) dan meramalkan permintaan Produksi Beras Merah di PT. Sirtanio Organik Indonesia yang berlokasi di Kecamatan Singojuruh, Kabupaten Banyuwangi. Peramalan permintaan adalah tingkat permintaan produk yang diharapkan untuk dapat direalisasikan pada jangka waktu tertentu di masa depan. Data yang digunakan sebagai input untuk penelitian ini adalah data harga, stok, penjualan dan permintaan beras merah organik pada periode tahun 2015-2017. Penelitian ini menggunakan enam arsitektur dan Algoritma yang digunakan adalah Artificial Neural Network Backpropagation. Hasil peramalan menunjukkan bahwa permintaan tertinggi untuk beras merah organik adalah pada bulan Agustus dan terendah pada bulan April 2018. Kesimpulan dari penelitian ini adalah arsitektur jaringan terbaik yaitu 3-20-1 dengan nilai $M S E=0,002, R$ squared $=0,859$, dan model jaringan syaraf tiruan yang dibentuk memiliki performa yang baik dalam memprediksi permintaan beras merah organik di Banyuwangi.
\end{abstract}

Kata kunci: Jaringan Syaraf Tiruan, propagasi balik, Banyuawangi, MSE, beras merah organik

\footnotetext{
${ }^{1}$ Corresponding author:

Email: abdulholik@poliwangi.ac.id
} 


\section{INTRODUCTION}

Banyuwangi is a rice producer in East Java with an average production of 306.073 tons and consumption of rice reaches 175.295 tons in 2018 (BPS, 2018). In general, farming in Banyuwangi still implements conventional rice farming systems, but in recent years begin to shift to organic rice farming systems to create environmentally friendly agriculture.

Organic rice is rice that is cultivated organically or without the application of chemical fertilizers and chemical pesticides, the rice is free from chemical fertilizer and pesticide residues (Mulyana et al. 2014). Organic rice is very good for health because it is free of harmful chemicals compared to conventional rice. A healthy lifestyle or back to nature has become a new trend of society because people are increasingly aware that the use of chemicals, synthetic pesticides and growth hormones in agricultural production can have a negative effect on human health (Sulistyana et al, 2014). Not the trend of a healthy lifestyle, but the price, nutritional content and product information in packaging is important to note (Idaman et al. 2012)

PT. Sirtanio Organik Indonesia is a company engaged in organic agriculture, located at $\mathrm{Jl}$. KH. Mahfud, Singojuruh - Banyuwangi which produces organic rice. Organic products that are produced by PT Sirtanio Organik Indonesia are red rice, black rice and white rice. Organic rice production in this company from 2015-2017 experienced a significant increase. Red rice is the highest production at PT. Sirtanio Organik Indonesia with an average production of 485 tons, black rice of 79.5 tons and white rice of 24.05 tons. Organic rice productivity is seen in Table 1.

Table 1 Organic rice production in 2015-2017 (ton).

\begin{tabular}{cccc}
\hline Year & Red Rice & Black Rice & White Rice \\
\hline 2015 & 138 & 21.5 & 77 \\
2016 & 156 & 20 & 73.5 \\
2017 & 191 & 38 & 89 \\
Average & 485 & 79.5 & 24.05 \\
\hline
\end{tabular}

Although Organic red rice productivity for the last three years is the highest production at PT. Sirtanio Organik Indonesia but Consumer demand always fluctuate each month as shown in Figure 1. The level of fluctuations will affect the pattern of production planning so that it disrupts the process of the company's activities.
Developed agricultural management need simple and accurate estimation techniques to predict rice production factors in the planning process (Dahikar et al. 2015). Companies need to manage production factors so that market demand for red rice production remains fulfilled. Therefore, demand forecasting is needed which is useful for knowing the level of future demand.

The use of artificial neural network (ANN) in forecasting has been widely carried out. Cassava production forecasting is carried out by Purba and Sitompul (2018). While (Revi et al. 2018) use ANN to predict rice production by province, while (Adi et al. 2018) predict rice production according to districts/ cities in North Sumatra. In addition, ANN is also used (Fardhani et al. 2018) to predict the retail price of rice in traditional markets in 33 cities in Indonesia. Whereas (Hartato et al. 2018) use ANN to predict the biopharmaceutical harvest area in Indonesia.

Research related to forecasting demands using ANN has also been carried out. Nurmayasari et al. (2018) Used ANN to forecast of demand for the BREM product market at home industry. Febrina et al. (2013) usedANN to forecast the number of requests for the production of v-belts and conveyor belts located in Tangerang. Mufaidah et al. (2017) predicted the number of frozen shrimp demand, while (Marjiyono et al, 2018) predicted demand in retail companies. Whereas (Aprilianto et al. 2018) predicted Sales in Supporting the Development of Chocolate Agroindustry in Blitar District. Although the use of ANN has been widely carried out, the use of ANN in predicting demand for organic red rice has never been used. The differences between the earlier research and this research are the commodity which is used organic red rice, the research location is in Banyuwangi, and the research variables are product prices, stocks, sales, and organic rice demand.

This research used ANN with a backpropagation algorithm. Backpropagation ANN method is an ANN method with a controlled learning algorithm and is used to minimize errors in the output produced by multilayer. This study aims to design an Artificial Neural Network (ANN) Architecture and forecast the demand of Red Rice Production at PT. Sirtanio Organik Indonesia which time series data used as input is product prices, stocks, sales and the demand in 2015-2017. 


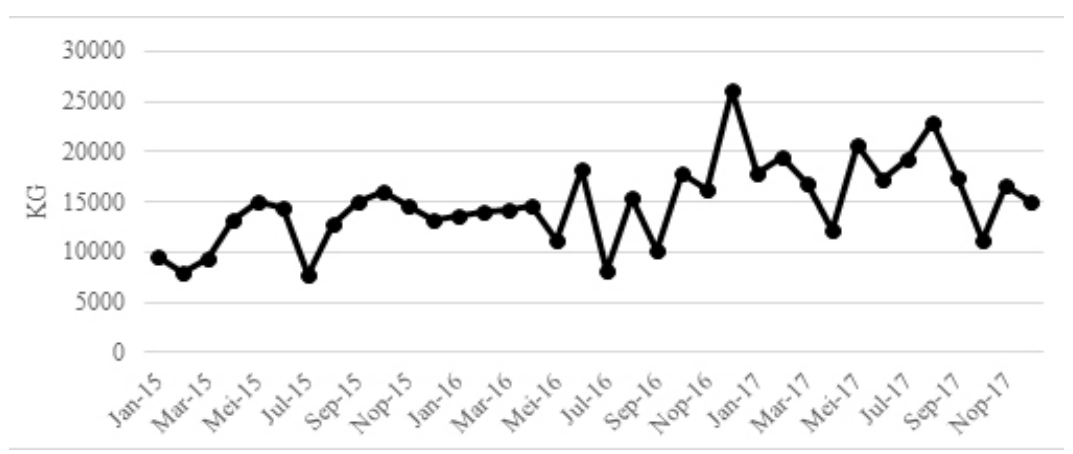

Figure 1. Demand for organic red rice 2015-2017

\section{METHODS}

This research was conducted at PT. Sirtanio Organik Indonesia located at Jl. KH. Mahfud, Singojuruh Banyuwangi. This company is engaged in organic agriculture such as: organic white rice, organic red rice, organic black rice, and organic fertilizer. The research was conducted on June 2018 - November 2018. The data used in this study are secondary data from 2015 to 2017 which collected from PT. Sirtanio Organik Indonesia, with the types of data as follows: Price of organic red rice $(\mathrm{Rp} / \mathrm{Kg})$, Production stock of organic red rice $(\mathrm{kg})$, Sales of organic red rice $(\mathrm{Kg})$, and demand of organic red rice demand $(\mathrm{Kg})$. All data used in this study are monthly data.

\section{Data Normalization}

Data normalization aims to prevent the network from failing when doing learning (training and testing). The data is normalized in intervals [0.1] because it is related to the binary sigmoid activation function.

$$
X^{\prime}=\frac{0,8 \times(x-a)}{(b-a)}+0,1
$$

Description: $\mathrm{X}^{\prime}$ (real data); a (minimum data); $\mathrm{b}$ (maximum data).

\section{Formation of ANN Architecture}

This study uses a 1 input layer consisting of 3 neurons namely product prices (X1), stocks (X2), and sales (X3). All neurons in this layer can be connected to neurons in hidden layers. There are 2 layers of hidden layer and 1 layer of output with 1 neuron namely demand (Y). this architecture was created to form patterns of relationships between neurons

\section{ANN Training}

Data training is a network model of calibration. Data training is to get the best network by determining the number of neurons. the data used in the training are data from 2015-2016. The training parameters are arranged so that the optimal results of the neural network architecture consist of the following stages:

Determine Maximum Learning Parameters

a. Maximum Epoch

Maximum epoch is the maximum amount of epoch allowed during the training process. The iteration will be stopped if the epoch value exceeds the maximum value of the epoch. The maximum epoch in this research is 2000 goals.

\section{b. Learning rate}

Learning rate is the rate of learning to accelerate the iteration rate (epoch). The greater the learning rate, the faster the training process will be. However, if the learning rate is too large, the algorithm becomes unstable. Conversely, if the learning rate is too small, the algorithm will converge for a very long time. Learning rate in this study is 0.01 .

\section{c. Momentum constant}

This function not only responds to local gradients but also considers the trends that have just occurred on the error surface. The magnitude of the change in weight is influenced by a constant known as the momentum number which is valued between 0 to 1 . The momentum of the constant in this study is 0.5 . 
Determine the Activation Function

Binary Sigmoid function (logsig \& tansig) is used in the process of weighing the input neurons into hiding with a range of 0 to 1 , while in the output layer the activation function used is a linear (identity) function.

\section{MSE (Mean Square Error)}

Mean Squared Error (MSE) is a method for measuring the accuracy of a forecasting model. The MSE value represents the average absolute error between the forecast results and the actual values. the equation used is:

$$
M S E=\sum \frac{(t-Y k)^{2}}{N}
$$

Description: $\mathrm{t}$ (target output value); yk (network output value); $\mathrm{N}$ (number of data).

\section{ANN Testing}

The data used in the testing is data in 2017. In testing or validation of the model is using the R-squared (R2). $\mathrm{R}$-squared is used to measure how far the ability of the model in explaining the variation of the dependent variable. The coefficient of determination is between 0 (zero) and 1 (one). A small R2 value means the ability of independent variables to explain the variation of the dependent variable is limited. the value close to one means that independent variables can be said to be stronger the model in explaining the influence of the independent variable (Ghazali, 2016).

This research begins with collecting price data, production stock, sales and demand data. The data is then normalized. after the ANN architecture is formed, data is trained and tested. Then forecasting can be done. this is shown in Figure 2.

\section{RESULTS}

The data obtained from observations are data on prices, stocks, sales results and demand of organic red rice in the period of January 2015 to December 2017 as in Table 2. Data on organic red rice prices from 2015 to 2017 tend to increase.
In 2015 prices rise from January to November, but prices fell down in December. In 2016, the price increased in July, while in other months it tended to be stable. Whereas in 2017 prices tend to be less stable (fluctuate). From the data, we can see that the price of rice is fluctuate. The price of agricultural production is always changing (unstable) when compared to prices of non-agricultural materials. This is due to the supply and demand curve for agricultural products is inelastic and there are changes that are difficult to predict on agricultural supplies due to agricultural production which is highly dependent on natural conditions (weather climate), pest diseases, and other factors (Anindita, 2004). Price movements reflect conditions developments in demand and supply, strength from the supply and demand side it has influence on changes and price fluctuations in world markets both exporters and importers markets (Khumaira et al. 2016).

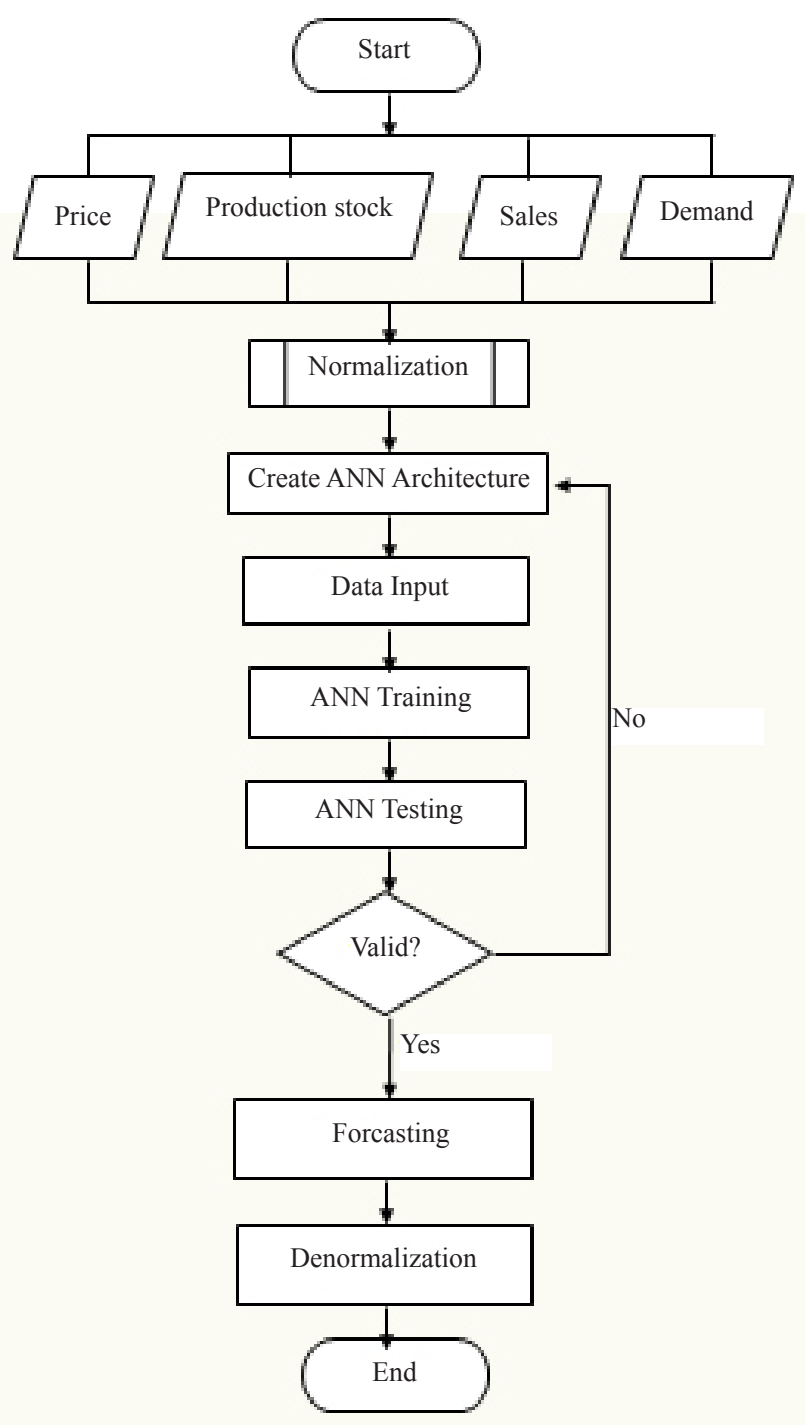

Figure 2. Research framework 
Table 2. Results of actual observations

\begin{tabular}{|c|c|c|c|c|c|}
\hline Year & Month & Price (Rp) & Stock (Kg) & Sales $(\mathrm{Kg})$ & Demand $(\mathrm{Kg})$ \\
\hline \multirow[t]{12}{*}{2015} & January & 14,900 & 9957 & 8771 & 9672 \\
\hline & February & 15,000 & 6993 & 7911 & 7958 \\
\hline & March & 15,350 & 8345 & 8357 & 9375 \\
\hline & April & 15,250 & 11238 & 12955 & 13295 \\
\hline & May & 15,300 & 14728 & 14548 & 14954 \\
\hline & June & 15,800 & 14198 & 13554 & 14353 \\
\hline & July & 15,600 & 7188 & 7563 & 7729,5 \\
\hline & August & 15,150 & 10144 & 12590 & 12782,5 \\
\hline & September & 15,250 & 15195 & 13962,5 & 14970,5 \\
\hline & October & 15,200 & 12941 & 15094 & 16069 \\
\hline & November & 15,450 & 14815 & 13474 & 14527 \\
\hline & December & 14,500 & 13157 & 11862 & 13127 \\
\hline \multirow[t]{12}{*}{2016} & January & 16,200 & 12866 & 8603 & 13561 \\
\hline & February & 16,000 & 12916 & 11109 & 14017 \\
\hline & March & 16,250 & 12967 & 10183 & 14133 \\
\hline & April & 16,300 & 7851 & 9505 & 14659 \\
\hline & May & 16,550 & 10767 & 7072 & 11199 \\
\hline & June & 16,150 & 16992 & 15291 & 18304 \\
\hline & July & 17,000 & 6774 & 3250 & 8142 \\
\hline & August & 16,300 & 12082 & 11221 & 15363 \\
\hline & September & 16,500 & 8565 & 6869 & 10223 \\
\hline & October & 16,200 & 17296 & 13690 & 17839,5 \\
\hline & November & 16,250 & 16364 & 11545 & 16277,5 \\
\hline & December & 16,150 & 21277 & 13755 & 26083 \\
\hline \multirow[t]{12}{*}{2017} & January & 16,800 & 17658 & 14417 & 17941 \\
\hline & February & 17,000 & 18396 & 10803 & 19518 \\
\hline & March & 17,400 & 14740 & 11065 & 16823 \\
\hline & April & 17,450 & 11675 & 8688 & 12283 \\
\hline & May & 17,000 & 19977 & 13742 & 20679 \\
\hline & June & 16,800 & 16523 & 13643 & 17259 \\
\hline & July & 17,200 & 18808 & 10246 & 19296 \\
\hline & August & 16,950 & 21183 & 16226 & 22993 \\
\hline & September & 17,000 & 16476 & 12034 & 17376 \\
\hline & October & 16,950 & 10510 & 5630 & 11182 \\
\hline & November & 17,050 & 12312 & 10673 & 16611 \\
\hline & December & 17,150 & 13687 & 8990 & 14954 \\
\hline
\end{tabular}

Beside the rice's price fluctuation, demand for organic red rice tends to fluctuate horizontally from 2015 to 2017 (Figure 1). This indicates that organic red rice demand fluctuates around the average. In early 2015 demand tended to increase, then dropped dramatically in July 2015 and became the lowest period. Demand fluctuations in 2016 and 2017 have a large gap, so it can be concluded that the demand for organic red rice in this period is still not stable. This instability of demand is caused by the response of the community to organic rice products that are still trying. The highest demand for organic red rice was in December 2016 of 26,083 $\mathrm{Kg}$, while the lowest demand was in July 2015 which was $7729.5 \mathrm{Kg}$. Demand is a function of various factors as; previous year's demand, the price of goods the price of other goods, per capita income, population, etc. Year request previously affected demand this year as a result of forming habits or habits formation (Kindangen et al. 2017). 
Data Normalization

The effectiveness of artificial neural networks with backpropagation is strongly influenced by data normalization to achieve the best accuracy.
Normalization used in this research is normalization min max. The results of data normalization are presented in Table 3.

Table 3. Data normalization results

\begin{tabular}{|c|c|c|c|c|c|}
\hline Year & Month & Price $(\mathrm{Rp})$ & Stock $(\mathrm{Kg})$ & Sales (Kg) & Demand $(\mathrm{Kg})$ \\
\hline \multirow[t]{12}{*}{2015} & January & 0.2085 & 0.2756 & 0.4404 & 0.1847 \\
\hline & February & 0.2356 & 0.1121 & 0.3874 & 0.1100 \\
\hline & March & 0.3305 & 0.1867 & 0.4149 & 0.1717 \\
\hline & April & 0.3034 & 0.3462 & 0.6983 & 0.3426 \\
\hline & May & 0.3169 & 0.5388 & 0.7965 & 0.4149 \\
\hline & June & 0.4525 & 0.5095 & 0.7353 & 0.3887 \\
\hline & July & 0.3983 & 0.1228 & 0.3659 & 0.1000 \\
\hline & August & 0.2763 & 0.2859 & 0.6758 & 0.3203 \\
\hline & September & 0.3034 & 0.5645 & 0.7605 & 0.4156 \\
\hline & October & 0.2898 & 0.4402 & 0.8302 & 0.4635 \\
\hline & November & 0.3576 & 0.5435 & 0.7303 & 0.3963 \\
\hline & December & 0.1000 & 0.4521 & 0.6309 & 0.3353 \\
\hline \multirow[t]{12}{*}{2016} & January & 0.5610 & 0.4360 & 0.4300 & 0.3542 \\
\hline & February & 0.5068 & 0.4388 & 0.5845 & 0.3741 \\
\hline & March & 0.5746 & 0.4416 & 0.5274 & 0.3791 \\
\hline & April & 0.5881 & 0.1594 & 0.4856 & 0.4020 \\
\hline & May & 0.6559 & 0.3203 & 0.3356 & 0.2512 \\
\hline & June & 0.5475 & 0.6636 & 0.8424 & 0.5609 \\
\hline & July & 0.7780 & 0.1000 & 0.1000 & 0.1180 \\
\hline & August & 0.5881 & 0.3928 & 0.5914 & 0.4327 \\
\hline & September & 0.6424 & 0.1988 & 0.3231 & 0.2087 \\
\hline & October & 0.5610 & 0.6804 & 0.7436 & 0.5407 \\
\hline & November & 0.5746 & 0.6290 & 0.6114 & 0.4726 \\
\hline & December & 0.5475 & 0.9000 & 0.7477 & 0.9000 \\
\hline \multirow[t]{12}{*}{2017} & January & 0.7237 & 0.7004 & 0.7885 & 0.5451 \\
\hline & February & 0.7780 & 0.7411 & 0.5657 & 0.6138 \\
\hline & March & 0.8864 & 0.5394 & 0.5818 & 0.4964 \\
\hline & April & 0.9000 & 0.3703 & 0.4353 & 0.2985 \\
\hline & May & 0.7780 & 0.8283 & 0.7469 & 0.6644 \\
\hline & June & 0.7237 & 0.6378 & 0.7408 & 0.5154 \\
\hline & July & 0.8322 & 0.7638 & 0.5313 & 0.6042 \\
\hline & August & 0.7644 & 0.8948 & 0.9000 & 0.7653 \\
\hline & September & 0.7780 & 0.6352 & 0.6416 & 0.5205 \\
\hline & October & 0.7644 & 0.3061 & 0.2467 & 0.2505 \\
\hline & November & 0.7915 & 0.4055 & 0.5576 & 0.4871 \\
\hline & December & 0.8186 & 0.4813 & 0.4539 & 0.4149 \\
\hline
\end{tabular}




\section{ANN Architecture and Training}

At the design and training of ANN is conducted by trial and error. The experiment is done by changing the number of hidden layer neurons from 4 to 24 hidden layers. The best architectural design is the number of hidden layer 20 neurons where the R squared $=0.859$, with MSE value of 0.002 (presented in Table 4), then the network architecture is validated and used as a reference in the forecasting process. while Figure 3 describes the relationship between training results and actual data.

\section{Validation Results (Testing)}

The validation data used is data in 2017. The mean square error (MSE) result is 0.0213 indicating fairly good performance. While the results of the mean absolute percentage error (MAPE) were $7.678 \%$. The results of the validation of organic red rice demand are presented in Table 5. as follows. Validation plot as shown in Figure 4 indicates that between simulation and actually has a very strong correlation. Evidenced by the value of $\mathrm{R} 2=0.91$ (Figure 5).

After the testing process, the forecasting process is carried out to forecast demand in 2018 . The forecasting results are still in the form of normalization data. To see the original data from forecasting, a denormalization process is carried out. The results of forecasting organic red rice demand in 2018 (Table 6) indicate that the highest demand is in August and the lowest demand is in October. The highest demand of rice usually occure during Indonesia's national holidays such as Ramadan, Christmas and New Year. Due to the necessity to provide large meals during these holidays, the consumer psychology is to increase the demand of meals and pay for food regardless of the cost (Kindangen et al. 2017).

Table 4. ANN Network Architecture with the best forecasting performance

\begin{tabular}{cccccc}
\hline \multirow{2}{*}{$\begin{array}{c}\text { Number of } \\
\text { hidden layers }\end{array}$} & Learning rate & \multicolumn{2}{c}{ Activation function } & \multirow{2}{*}{ MSE } & R-squared \\
\cline { 3 - 4 } & & Hidden & output & & 0.0026 \\
8 & 0.01 & logsig & tansig & & 0.620 \\
8 & 0.01 & logsig & tansig & 0.0476 & -0.685 \\
12 & 0.01 & logsig & tansig & 0.0021 & 0.733 \\
16 & 0.01 & logsig & tansig & 0.0071 & 0.836 \\
20 & 0.01 & logsig & tansig & 0.0020 & 0.859 \\
24 & 0.01 & logsig & tansig & 0.0053 & 0.796 \\
\hline
\end{tabular}

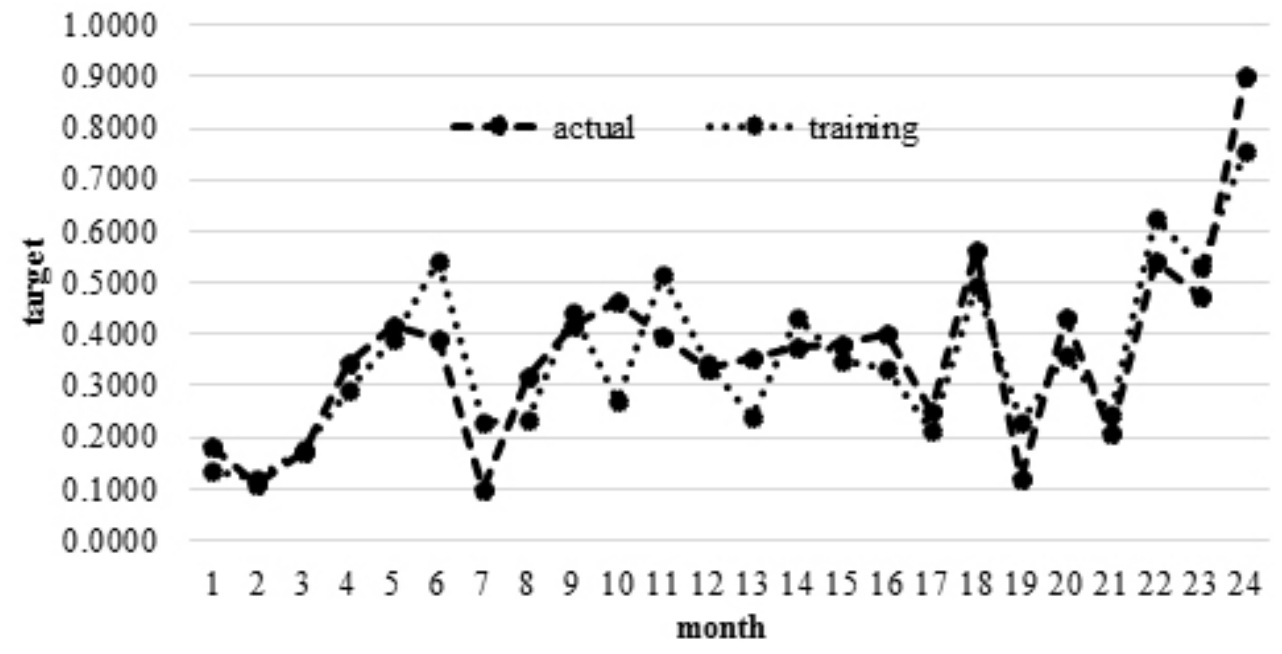

Figure 3. plot of actual demand and training results 
Table 5. The results of the validation of organic red rice demand

\begin{tabular}{clccccc}
\hline \multirow{2}{*}{ Year } & Month & actual demand & validation & error & squared error & $\begin{array}{c}\text { Absolute } \\
\text { percentage error (\%) }\end{array}$ \\
\hline \multirow{2}{*}{2017} & January & 0.5451 & 0.6001 & -0.0550 & 0.0030 & 10.082 \\
& February & 0.6138 & 0.5772 & 0.0366 & 0.0013 & 5.966 \\
& March & 0.4964 & 0.4787 & 0.0177 & 0.0003 & 3.556 \\
& April & 0.2985 & 0.3596 & -0.0611 & 0.0037 & 20.486 \\
& May & 0.6644 & 0.6604 & 0.0040 & 0.0000 & 0.597 \\
& June & 0.5154 & 0.5570 & -0.0416 & 0.0017 & 8.081 \\
& July & 0.6042 & 0.5844 & 0.0198 & 0.0004 & 3.279 \\
& August & 0.7653 & 0.7247 & 0.0406 & 0.0016 & 5.302 \\
& September & 0.5205 & 0.5372 & -0.0167 & 0.0003 & 3.212 \\
& October & 0.2505 & 0.2823 & -0.0318 & 0.0010 & 12.678 \\
& November & 0.4871 & 0.3986 & 0.0885 & 0.0078 & 18.173 \\
& December & 0.4149 & 0.4179 & -0.0030 & 0.0000 & 0.724 \\
\hline
\end{tabular}

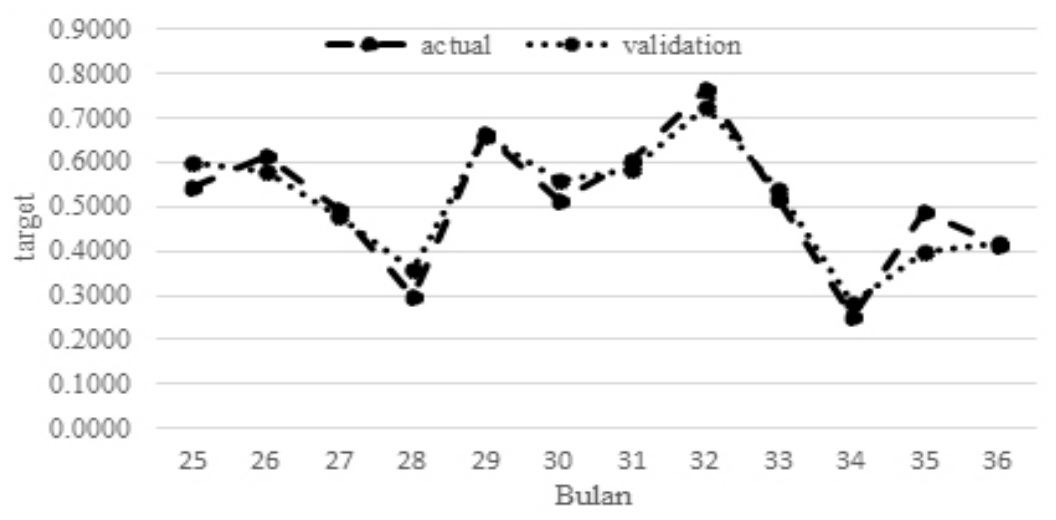

Figure 4. Actual request plot and validation results

\section{Managerial Implications}

Some managerial implications that can be applied by the management at PT. Sirtanio Organik Indonesia are; For Directors, the results of this study can be used as a material for consideration and evaluation of the opportunities, processes, problems, and performance of the company, especially those related to the production and demand for organic red rice. It can also be used as a reference for improvement and increasing production capacity of organic red rice.

For the Marketing Division, the forecasting it can be used to determine the marketing and promotion plans for organic red rice in the future. Marketing and promotion plans can be further enhanced if demand forecasting results show low results so that with the right marketing and promotion can further increase the demand for organic red rice.
For the Production Division, the forecasting result can be used to determine the amount of production of organic red rice to be produced. So that the total product produced can be maximal. For the Finance Division, it can maximize the benefits that will be obtained by PT. Sirtanio Organik Indonesia. The production of organic red rice in accordance with the results of forecasting demand for organic red rice can maximize the company's sales. So, the results of the profits obtained can also be maximized.

For the Cultivation Division, the forecasting results of organic red rice can be used to determine the number of plants to be planted by the cultivation division. Conformity between the number of plants that will be cultivated and the amount of demand for organic red rice is very necessary in order to obtain effective and efficient production. If the forecasting results of the demand for organic red rice are high, the cultivation 
division must also plant large amounts of red rice. On the contrary, if the forecast demand for organic red rice shows a low yield, the number of organic red rice plants cultivated is also small, so there is no accumulation of organic red rice stock.

\section{CONCLUSIONS AND RECOMMENDATIONS}

\section{Conclusions}

Based on the research that has been done on the forecasting of organic red rice, the best network architecture is built from 20 hidden layers, the learning rate 0.01 with the resulting MSE is 0.002 and the resulting $\mathrm{R}$ squared is 0.859 . Validation performance shows satisfactory results with R squared 0.91, MSE $=0.0018$ and MAPE $=7,678 \%$. Forecasting results indicate that the highest demand for organic red rice is in August amounting to $22.259 \mathrm{~kg}$ and the lowest in April is $12.809 \mathrm{~kg}$. The formation of an ANN network can use other variables such as the number of consumer requests, consumer income, and taste. The accuracy of forecasting results requires a long time span so that longtime series data is needed.

\section{Recommendations}

There are several recommendations that can be given from this research such as: The formation of an ANN network can use other variables such as the number of consumer requests, consumer income, and taste. The accuracy of forecasting results requires a long time period so that long time series data is needed.

\section{REFERENCES}

Adi M et al. 2018. Penerapan algoritma backpropagation dalam memprediksi produksi tanaman padi sawah menurut kabupaten/kota di Sumatera Utara. SemanTIK 4(1): 77-86. https://doi. org/10.21776/ub.habitat.2018.029.3.16.

Anindita R. 2004. Pemasaran Hasil Pertanian. Jakarta: Papirus.

Aprilianto H, Kumalaningsih S, Santoso I. 2018. Penerapan jaringan syaraf tiruan untuk peramalan penjualan dalam mendukung pengembangan agroindustri coklat di kabupaten Blitar." Habitat 29(3): 129-37.

[BPS] Badan Pusat Statistik. 2018. Rice production by regency / city in Jawa Timur, 2018 (Ton). https:// jatim.bps.go.id/subject/53/tanaman-pangan. html\#subjekViewTab3.

Dahikar, Snehal SPG, Student E, Sipna C. 2015. An artificial neural network approach for agricultural cropyield prediction based on various parameters. International Journal of Advanced Research in Electronics and Communication Engineering (IJARECE) 4(1): 94-98.

Fardhani A ,Insani D, SimanjuntakN, Wanto A. 2018. Prediksi harga eceran beras di pasar tradisional di 33 kota di Indonesia menggunakan algoritma backpropagation. Jurnal Infomedia 3(1): 25-30. https://doi.org/10.30811/jim.v3i1.625.

Febrina M, Arina F, Ekawati R. 2013. Peramalan jumlah permintaan produksi menggunakan metode jaringan syaraf tiruan (JST) backpropagation. Teknik Industri 1(2): 174-79.

Ghazali I. 2016. Aplikasi analisis multivariate dengan program IBM SPSS 23. 8th ed. Semarang: BPFE Universitaas Diponegoro.

Hartato E, Sitorus D, Wanto A. 2018. Analisis jaringan saraf tiruan untuk prediksi luas panen biofarmaka di Indonesia. Jurnal semanTIK 4(1): 49-56. https://doi.org/10.26594/register.v4i1.1157.

Idaman N, Yuliati LN, Retnaningsih. 2012. Sikap konsumen terhadap beras organik. Jurnal Manajemen \& Agribisnis 9(2): 117-26.

Khumaira K, Hakim DB, Sahara S. 2016. Transmisi harga kopi antara pasar indonesia dengan pasar tujuan ekspor utama. Jurnal Manajemen dan Agribisnis 13(2): 98-108. https://doi. org/10.17358/JMA.13.2.98.

Kindangen H, Hartoyo S, Baga LM. 2017. Perkembangan produktivitas, luas lahan, harga domestik, permintaan dan ekspor biji kakao Indonesia periode 1990-2013. Jurnal Manajemen dan Agribisnis 14(2): 118-26. https://doi. org/10.17358/jma.14.2.118.

Marjiyono SB, Taufiq EL. 2018. Penggunaan jaringan syaraf tiruan untuk meramalkan permintaan pada perusahaan retail. In Seminar Nasional Teknologi Informasi Dan Multimedia, 7-12.

Mufaidah I, Suwasono S, WibowoY, Soedibyo DW. 2017. Peramalan jumlah permintaan udang beku pnd menggunakan metode jaringan syaraf tiruan (JST) backpropagation. Jurnal Agroteknologi 11(01): 17-22. https://doi.org/10.19184/j-agt. v11i1.5438.

Mulyana A, Lifianthi, Sari DW. 2014. Konsumsi dan stok beras organik dan anorganik rumah tangga 
di kota Lubuk Linggau. In Prosiding Seminar Nasional Lahan Suboptimal, 1-7.

Nurmayasari PD, Widaningrum I, Astuti IP, Arifin R. 2018. Prediksi jumlah permintaan pasar produk brem dengan menggunakan jaringan syaraf tiruan metode propagasi mundur. Multitek Indonesia 12(1): 58-64. https://doi.org/10.24269/mtkind. v12i1.1205.

Purba ZN, Sitompul D. 2018. Analisis tingkat akurasi algoritma backpropagation dalam prediksi produksi ubi kayu di provinsi Indonesia. Jurnal
Riset Sistem Informasi dan Teknik Informatika 3(3): 87-97. https://doi.org/10.30645/jurasik. v3i0.68.

Revi A, Parlina I, Safii M. 2018. Model jaringan syaraf tiruan memprediksi produksi padi Indonesia berdasarkan provinsi. Jurnal Teknovasi 5(2): 1-13. https://doi.org/10.30865/komik.v2i1.941.

Sulistyana P, Mulyo JH, Jamhari. 2014. Konsumsi beras organik pada tingkat rumah tangga di kota Yogyakarta. Agro Ekonomi 24(1): 25-34. https:// doi.org/10.22146/agroekonomi.17357. 